\title{
Characterization of probiotic Bacillus subtilis isolated from \\ Nile tilapia (Oreochromis niloticus) digestive tract and evaluation its positive impact on health and nonspecific immunity of Nile tilapia Mahmoud Mohamed EL-Adawy
}

Fish health and mangment department, Central Laboratory for Aquaculture Research, Abbaasa, Abu-Hammad, Sharkia, Egypt.

Received: May. 13, 2019; Accepted: May. 29, 2019 published: Vol.9 (2):01-26; 2019

\section{Abstract}

In the present study, a probiotic, Bacillus subtilis was isolated and identified from the digestive tract of freshwater Nile tilapia collected from production ponds of the Central Laboratory of Aquaculture Research, Egypt. The isolated strain of Bacillus subtilis was biochemically identified using API $20 \mathrm{E}$ and $16 \mathrm{~S}$ rRNA. The biosafety assay confirmed that the isolate was not pathogenic to Nile tilapia fish. Isolated strain was able to survive at increasing concentrations of bile. The isolated strain was sensitive to most used antibiotics. The Isolated strain showed antagonistic activity against bacterial fish pathogens, including Aeromonas hydrophila and Pseudomonas aeruginosa. In addition, the isolated strain did not show any hemolytic activity against human blood in the blood agar medium. To evaluate the positive impact of the supplementation of an isolated strain of Bacillus subtilis on hematological, biochemical and immunological parameter of Nile tilapia. A total of 120 fish ( $20 \mathrm{~g})$ were randomly divided into 2 groups (control and treatment with 3 replicates). The control groups were fed the basal diet. Treatment groups were supplemented with $B$. subtilis $1 \times 10^{9} \mathrm{cfu} / \mathrm{g}$. Results showed that Nile tilapia fed with diets containing B.subtilis for 7 weeks had a significant increase in $\mathrm{Hb} \%$, RBCs count, HCT values and WBCs count. Also, there is a significant improvement in liver function test (ALT, AST, Total protein and Albumin). Also, there is a significant increase in immunological parameter (NBT, Lysozyme). Moreover, fish fed with B.subtilis supplemented diets showed improved survival rates after $A$. hydrophila infection. 
Keyword: Bacillus subtilis, Nile tilapia, API 20E, Positive impact.

\section{INTRODUCTION}

The rapid development of aquaculture from last years has increased feed ingredients demand and its prices, for this reason feeding represent $40-60 \%$ of the total production. Probiotics are live microorganisms able to establish, multiply and colonize the intestine of the host in order to promote a beneficial balance of microorganisms. These benefits are explain due to these microorganisms improve the digestibility, absorption of nutrients and inhibit the proliferation of harmful agents in the intestinal mucosa, (Nayak, 2010), promote the synthesis of vitamins (Lee et al., 2013), and improve the growth performance of animals (Mohapatra, et al., 2013) by increasing the survival percentage (Wu et al., 2014) and water quality (Chi, et al., 2014). Bacteria of the Bacillus genus are among the most widespread microorganisms in nature, they can be found in soil, water and air. Bacillus constitutes a diverse group of rod-shaped, Grampositive bacteria, characterized by their ability to produce a robust spore (Sonnenschein, et al., 1993). The intestinal microbe is an important component of mucosal barrier has resulted in the promotion of the use of beneficial probiotic (Gomes, 2008). Bacteria from genus Bacillus are one of the main probiotics used in aquaculture. These bacteria are ease to cultivate and form spores, which facilitates its conservation (Nayak, 2010; Han, et al., 2015). In addition, several bacteria of this genus have the capacity to secrete antimicrobial compounds and different exoenzymes that aid digestion (Ziaei-Nejad, et al., 2006). Probiotic bacteria could produce digestive enzymes and essential growth nutrients such as amino acids and vitamins, which are benefit for enhancing the best growth, also they could benefit to their invertebrate host by competitive exclusion against pathogens (Austin, et al., 1995; GomezGil, et al., 2000) or by increasing the host immunity and resistance (Uma, et al., 1999) which are benefit to achieve the higher survival rate and healthier animals. The use of probiotics in the aquaculture is increasing with demand for more environment friendly aquaculture practices (Gatesoupe, 1999). The aim of this study was to isolate probiotic Bacillus subtilis from the Nile tilapia digestive tract, identification of the isolated strain, Biosafety. assay, probiotic prosperities and evaluation the positive impact of isolated stain on Nile tilapia health and immunity. 


\section{MATERIAL AND METHODS}

\section{Fish sample}

Healthy fresh water Nile tilapia samples with an average weight of $100 \mathrm{~g}$ were collected from the production pounds of Central laboratory for Aquaculture Research (CLAR) and transported alive to the laboratory of Fish Health and Management Department, Central Laboratory for Aquaculture Research.

\section{Isolation of gut bacteria}

Under complete aseptic conditions, the fish digestive tract was dissected out and homogenized with $5 \mathrm{ml}$ of normal saline. To remove fungal contaminants, the homogenate was kept in a boiling water bath for $20 \mathrm{~min}$ at $80{ }^{\circ} \mathrm{C}$. The homogenate was serially diluted and pour plated onto Bacillus agar medium. Plates were incubated for $24 \mathrm{~h}$ at $28{ }^{\circ} \mathrm{C}$ under aerobic conditions. Individual colonies were picked up and purified by streaking method in a fresh Bacillus agar medium. Bacterial isolates were identified and stored at $-80{ }^{\circ} \mathrm{C}$ in nutrient broth supplemented with $40 \%$ glycerol according (Priest, et al., 1987).

\section{Biochemical characterization}

The isolated bacteria was characterized by standard bacteriological methods according to (Boone, et al., 2005).

\section{API-20E microbiological identification}

Further identification of the isolates was performed by API-20E microbial identification kit (BioMerieux ). The sample was prepared by suspending a single colony from a fresh culture into $5 \mathrm{ml}$ of sterile saline solution. Then the suspension was carefully inoculated in all the tube sections according to the manufacturer's instructions. All incubations were done at $28 \cdot \mathrm{C}$.

\section{Molecular identification}

DNA extraction. DNA extraction from sample was performed using the QIAamp DNA Mini kit (Qiagen, Germany, GmbH) with modifications from the manufacturer's recommendations. Briefly, $200 \mu 1$ of the sample suspension was incubated with $10 \mu \mathrm{l}$ of proteinase $\mathrm{K}$ and $200 \mu \mathrm{l}$ of lysis buffer at $56^{\circ} \mathrm{C}$ for $10 \mathrm{~min}$. After incubation, $200 \mu \mathrm{l}$ of $100 \%$ ethanol was added to the lysate. The sample was then washed and centrifuged following the manufacturer's recommendations. Nucleic acid was eluted with $100 \mu \mathrm{l}$ of elution buffer provided in the kit.

Oligonucleotide Primer. Primer used was supplied from Metabion (Germany) are listed in table (1). 
Table (1): Primers sequences, target genes, amplicon sizes and cycling conditions for conventional PCR.

\begin{tabular}{|c|c|c|c|c|c|c|c|c|}
\hline \multirow{2}{*}{$\begin{array}{l}\text { Target } \\
\text { gene }\end{array}$} & \multirow[t]{2}{*}{ Primers sequences } & \multirow{2}{*}{$\begin{array}{c}\text { Ampli } \\
\text { fied } \\
\text { segme } \\
\text { nt } \\
\text { (bp) }\end{array}$} & \multirow{2}{*}{$\begin{array}{c}\text { Prima } \\
\text { ry } \\
\text { denat } \\
\text { uratio } \\
\text { n }\end{array}$} & \multicolumn{3}{|c|}{ Amplification ( 35 cycles) } & \multirow{2}{*}{$\begin{array}{c}\text { Final } \\
\text { extens } \\
\text { ion }\end{array}$} & \multirow[t]{2}{*}{ Reference } \\
\hline & & & & $\begin{array}{l}\text { Second } \\
\text { ary } \\
\text { denatu } \\
\text { ration }\end{array}$ & $\begin{array}{l}\text { Anneal } \\
\text { ing }\end{array}$ & $\begin{array}{c}\text { Exten } \\
\text { sion }\end{array}$ & & \\
\hline \multirow{3}{*}{$\begin{array}{c}\text { B. } \\
\text { subtilis } \\
\text { Group } \\
16 S \\
\text { rRNA }\end{array}$} & $\begin{array}{c}\text { AAGTCGAGCGG } \\
\text { ACAGATGG }\end{array}$ & \multirow[t]{3}{*}{$\begin{array}{l}595 \\
\text { bp }\end{array}$} & \multirow[t]{3}{*}{$\begin{array}{l}94^{\circ} \mathrm{C} \\
5 \mathrm{~min} .\end{array}$} & \multirow[t]{3}{*}{$\begin{array}{c}94^{\circ} \mathrm{C} \\
30 \mathrm{sec} .\end{array}$} & \multirow[t]{3}{*}{$\begin{array}{l}55^{\circ} \mathrm{C} \\
40 \mathrm{sec} .\end{array}$} & \multirow{3}{*}{$\begin{array}{c}72^{\circ} \mathrm{C} \\
45 \\
\text { sec. }\end{array}$} & \multirow[t]{3}{*}{$\begin{array}{c}72^{\circ} \mathrm{C} \\
10 \\
\text { min. }\end{array}$} & \multirow{3}{*}{$\begin{array}{c}\text { Wattiau } \\
\text { et al., } \\
2001\end{array}$} \\
\hline & $\begin{array}{c}\text { CCAGTTTCCAAT } \\
\text { GACССТСССC }\end{array}$ & & & & & & & \\
\hline & $\begin{array}{c}\text { GGTGATCGATC } \\
\text { ACCACCAGC }\end{array}$ & & & & & & & \\
\hline
\end{tabular}

PCR amplification. Primer was utilized in a $25-\mu 1$ reaction containing $12.5 \mu 1$ of EmeraldAmp Max PCR Master Mix (Takara, Japan), $1 \mu 1$ of each primer of 20 pmol concentration, $4.5 \mu 1$ of water, and $6 \mu 1$ of DNA template. The reaction was performed in an Applied biosystem 2720 thermal cycler

\section{Analysis of the PCR Products.}

The products of PCR were separated by electrophoresis on $1.5 \%$ agarose gel (Applichem, Germany, GmbH) in 1x TBE buffer at room temperature using gradients of $5 \mathrm{~V} / \mathrm{cm}$. For gel analysis, $20 \mu \mathrm{l}$ of the PCR products were loaded in each gel slot. Gelpilot 100 bp ladder (Qiagen, Gmbh, Germany) was used to determine the fragment sizes. The gel was photographed by a gel documentation system (Alpha Innotech, Biometra).

\section{Bio-safety assay}

Sixty apparently healthy Nile tilapia of average weight $20 \mathrm{~g}$ were obtained from production ponds of CLAR, were divided into two groups with 3 replicates . fish were acclimatized under laboratory condition for 7 days. Experimental fish were injected intraperitoneally with $100 \mu \mathrm{l}$ of bacterial suspension (approximately $10^{9} \mathrm{CFU} / \mathrm{ml}$ ), whereas the control groups were injected with sterile saline (Mukherjee \& Ghosh, 2016). All groups were fed at 5\% of the body weight per day for 7 days divided into two time daily. All injected fish were subjected for close observation for any abnormal alteration for 7 days post injection. Also fish were sacrificed and examined the disease symptoms ( Sharifuzzaman \& Austin, 2009) 
Screening for probiotic properties:-

Bile tolerance

From gall bladder of apparently heath Nile tilapia crude bile was collected, using a syringe and stored at $-20{ }^{\circ} \mathrm{C}$ until use. To assess the bile tolerance, the $500 \mu \mathrm{l}$ of the fresh bacterial suspension $\left(10^{8} \mathrm{CFU} \mathrm{ml}^{-1}\right)$ of the test culture was added in $10 \mathrm{ml}$ medium supplemented with 2.5 , 5.0, 7.5 and $10 \%(\mathrm{v} / \mathrm{v})$ of bile salts. All bacterial were incubated at 28 ${ }^{\circ} \mathrm{C}$. for 3 and $6 \mathrm{~h}$ and survivability of the isolates was monitored by culturing $0.1 \mathrm{ml}$ on the Bacillus agar plate. Growth medium with $0 \%$ bile served as control and survivability of the isolate was represented in percentage. (Nikoskelainen, et al., 2001).

\section{Haemolytic activity}

The isolated strain of B.subtilis was subjected to a hemolytic activity, according to (Argyri, et al., 2013). Bacillus subtilis was streaked on blood agar plates containing 5\% (w/v) human blood and incubated for 48 $\mathrm{h}$ at $28^{\circ} \mathrm{C}$.

\section{Antibiotic sensitivity:-}

The sensitivity of isolated probiotic Bacillus subtilis to different antibiotics was determined according to . (Bauer, et al, 1966).

\section{Antimicrobial activity}

The antagonistic property of Bacillus subtilis against pathogenic strains of Aeromonas hydrophila and pseudomonas aeruginosa was performed according to (Ahire, et al., 2011).

Evaluation of positive impact of the isolated strain of Bacillus subtilis on Nile tilapia health and immunity:-

\section{Diet preparation}

Bacillus subtilis culture was grown for $48 \mathrm{~h}$ at $28^{\circ} \mathrm{C}$ in Tryptic soya broth. The culture was centrifuged at $4000 \mathrm{~g}$ for $10 \mathrm{~min}$ at $4^{\circ} \mathrm{C}$, was washed three times in $0.9 \%(\mathrm{w} / \mathrm{v})$ saline, and was prepared a suspension in $0.9 \%(\mathrm{w} / \mathrm{v})$ saline (Newaj, et al., 2007). Commercial feed (Aler aqua) was used as the basal diet for the supplementation of probiotic strains. Bacillus subtilis strain was sprayed into the feed to give a final concentration of $1 \times 10^{9} \mathrm{CFU} / \mathrm{g}$ according to (Kuan., et al 2010)Then the feed was oven-dried at $35^{\circ} \mathrm{C}$ for $1-2 \mathrm{~h} .200 \mathrm{~g}$ portions of the feed were packed in sealed plastic bags and stored at $4^{\circ} \mathrm{C}$ for 2 weeks until used.

\section{Experimental design}

The total numbers of 120 apparently healthy Nile tilapia with average body weight of $(20 \pm 1 \mathrm{~g})$ were obtained from production ponds of 
CLAR. Fish were acclimated to the laboratory conditions for one week . In well equipped 6 glass aquaria $(80 \times 40 \times 50 \mathrm{~cm})$ filled with dechlorinzed tap water at $25 \pm 1^{\circ} \mathrm{C}$ and continuous aeration using air pumps in the wet laboratory fish were divided into two groups ( Control and treatment groups) with 3 replicates. Fish were fed at a rate of $5 \%$ from the biomass and about half of the water was changed with chlorine free water and fecal matters were siphoned out once daily during the experiment. Fish were fed twice daily on standard commercially prepared pellets $30 \%$ protein (Aler aqua). Control groups were fed on basal diet and treatment groups were supplemented with B.subtilis $1 \times 10^{9} \mathrm{cfu} / \mathrm{g}$ for 7 weeks .

\section{Blood sampling}

Collection of blood was carried out according to (Lied, et al., 1975). For serum separation, peripheral blood was clotted at $4{ }^{\circ} \mathrm{C}$ for $4 \mathrm{~h}$. Blood clots were centrifuged at $10,000 \times \mathrm{g}$ for $10 \mathrm{~min}$ and stored at $-20{ }^{\circ} \mathrm{C}$ for use in determination of biochemical parameter and lysozyme activity. Remaining blood was placed in $0.6 \mathrm{ml}$ plasma separation tubes containing heparin-lithium for use in the determination of hematological parameter and Nitroblue tetrazolium.

\section{Hematological parameters}

Hemoglobin concentration was determined using the cyanomethemoglobin method according to ( Stoskopf, 1993 ). Packed cell volume was estimated by the micro-haematocrite method described by ( Decie $\&$ Lewis, 1991) A manual method for counting RBCs using a hemocytometer counting chamber and Natt-Herrik solution was carried out according to ( Stoskopf, 1993). WBC count were estimated according to ( Thrall, 2004).

\section{Biochemical parameters}

Alanine aminotransferase activity (ALT) and Aspartate aminotransferase activity (AST) were performed according to ( Reitman \& Frankel, 1957). Assay of total proteins and albumin were carried by a test kit according to biuret method described by (Weichselbaum , 1946).

\section{Immunological parameters}

\section{Lysozyme assay}

Lysozyme activity was measured using spectrophotometer with attachment for turbidity measurement. A series of dilution was prepared by diluting the standard lysozyme from hen egg- white and mixed with 
Micrococcus lysodeikticus (ATCC No.4698) suspension for establishing the calibration curve. $50 \mu \mathrm{l}$ of standard or serum was added in cuvtts to $1.0 \mathrm{ml}$ of Micrococcus lysodeikticus suspension. The change in the extinction was measured at $620 \mathrm{~nm}$, by measuring the extinction immediately after adding the solution which contained the Lysozyme (start of the reaction) and after 20 minute incubation of the preparation under investigation at $40{ }^{\circ} \mathrm{C}$. (end of reaction). The Lysozyme content is determined based on the calibration curve and extinction measured according to ( Schäperclaus, et al, 1992).

\section{Nitroblue tetrazolium (NBT)}

After fish bleeding, $100 \mu \mathrm{L}$ of heparinised blood was added to $100 \mu \mathrm{L}$ of $0.2 \%$ nitroblue tetrazolium solution (NBT, Sigma,) and the final solution was homogenised and incubated for 30 minutes at $25{ }^{\circ} \mathrm{C}$. The NBT solution was prepared in phosphate buffered saline (pH 7.4). After incubation and a second homogenisation, $50 \mu \mathrm{L}$ from the solution were added to $1 \mathrm{ml}$ of $\mathrm{N}, \mathrm{N}$-dimethyl formamide (DMF, Sigma,) in a glass tube. This new solution was homogenised and centrifuged at $3000 \mathrm{~g}$ for 5 minutes. The optical density (OD) of supernatant was determined on spectrophotometer at $540 \mathrm{~nm}$. The blank consisted of the same components and steps except blood that was exchanged with distilled water. The values of the extinction here were transposed according to a standard curve into $\mathrm{mg}$ of NBT/ $1 \mathrm{ml}$ of blood. Extinction reading X $4=$ $\mathrm{mg}$ NBT formazan/ $1 \mathrm{ml}$ of blood according to ( Siwicki, 1989).

\section{Challenge test and estimation of relative percent of survival:-}

The fish pathogen, Aeromonas hydrophila was previously isolated and biochemically identified from clinically diseased Nile tilapia, in fish health and management department, CLAR. After 7 weeks of feeding , $20 \mathrm{fish} /$ replicate were intraperitoneal injected with $0.1 \mathrm{ml}$ pathogenic $A$. hydrophila (containing $1.5 \times 10^{8}$ cells $/ \mathrm{ml}$ ). Clinical signs, postmortem lesions and daily mortalities were monitored for 14 days . The reisolation of A. hydrophila from the kidney, and intestine of morbid fish confirmed the infection. The average mortality among all replicates was used to calculate the relative percent survival (RPS) (Amend, 1981).

\section{Statistics}

All data were analyzed using Independent Sample T Test. The results are displayed as mean values with their standard errors (mean \pm SE) using the statistical package SPSS 19.0 (IBM SPSS statistics). 


\section{Results}

\section{Identification of the bacteria isolated from the Nile tilapia gut:-}

After $24 \mathrm{~h}$ of incubation under aerobic conditions, colonies appeared on the Bacillus agar medium. The biochemical characteristics of isolated probiotic Bacillus subtilis were illustrated in table (2), Fig $(1,2)$ in which the isolated bacteria was, gram positive, bacilli, positive for Catalase, Oxidation, Citrate utilization, Gelatin hydrolysis, VP, Nitrate reduction, Gelatinase, and Glucose ,Sucrose, Sorbitol, Rhamnose, Inositol and manitol fermentation. The strain was negative for Arginine dihydrolase, ,Indole production, Tryptophan, Lysine decarboxylase, Ornithine decarboxylase, Urea hydrolysis, Melibiose, Arabinose , Amygdalin and Bata galactosidase .The PCR technique was successfully detected the $16 \mathrm{~s}$ rRNA Bacillus subtilis at gene locus 595 bp(Fig.,3).

\section{Bio-safety assay:-}

In the present study, in vivo biosafety assay, all control and the experimental groups did not show any pathological alteration or mortalities as recorded after 7 days (after I/P injections of probiotic) of observation.

\section{Screening for probiotic properties :-}

\section{Bile tolerance}

The B.subtilis isolate was able to survive at increasing concentration of bile, showed higher survivability of $71,68,65$ and $55 \%$ at 2.5, 5.0, 7.5 , and $10 \%$ of bile salt, respectively after $3 \mathrm{~h}$ of incubation. However, after $6 \mathrm{~h}$ incubation the survivability was reduced to 50.0, 47.0, 45.0 and $40 \%$, respectively at increasing concentration of bile salt. As shown in table (3).

\section{Haemolytic activity}

The isolated Bacillus subtilis strain had no clear transparent or greenish zone surrounding their colonies on the blood agar plates. The B.subtilis had no haemolytic activity against human blood in the blood agar medium as shown in Fig (4).

\section{Antibiotic sensitivity}

The isolated study the isolated Bacillus subtilis was sensitive to Norfloxacin, Levofloxacin, Streptomycin, Gentamycin, Trimethoprime /sulphamethoxazole, Amoxicillin and Ampicillin /sulbactam on the other hand, it was resistant to Cefuroxime and Flucloxacillin . Table (4) Fig (5). 


\section{Antimicrobial activity}

The observed results of the antimicrobial effect of the probiotic $B$. subtilis against selected fish pathogen showed that the probiotic $B$. subtilis was efficient in inhibiting the growth of fish pathogen Aeromonas hydrophila and Pseudomonas aeruginosa. Fig ( 6,7).

Evaluation of positive impact of the isolated strain of B.subtilis on Nile tilapia health and immunity:-

\section{Hematological parameter:-}

Results of hemoglobin concentration, RBCs count, HCT values, WBCs count were summarized in table (5). It shows that fish fed diet supplemented with B. subtilis at concentration of $1 \times 10^{9} \mathrm{cfu} / \mathrm{g}$ significantly increased of the examined blood parameters. compared with the control group.

\section{Biochemical parameters.}

The results of liver enzymes ( AST, AST ), total protein and albumin showed significant improvement in fish fed diet containing probiotic

( $1 \mathrm{X} 10^{9} \mathrm{CFU} / \mathrm{g}$ feed ) compared with the control groups. (table ,6 ).

\section{Immunological parameter}

\section{Lysozyme activity:-}

As shown in table (7), serum lysozyme of the fish fed diet containing probiotics $\left(1 \mathrm{X} 10^{9} \mathrm{CFU} / \mathrm{g}\right.$ feed) had significantly higher activity than the control groups after 7 weeks of feeding $(3.20+0.034 \mu \mathrm{g} / \mathrm{mL})$ Nitroblue tetrazolium (NBT)

As shown in table (7), NBT activity of the fish fed diet containing probiotics $\left(1 \mathrm{X} 10^{9} \mathrm{CFU} / \mathrm{g}\right.$ feed) had significantly higher activity than the control groups after 7 weeks of feeding $(0.644+0.06 \mathrm{mg} / \mathrm{mL})$.

\section{Challenge test}

After 14 days post-infection of $A$. hydrophila, the obtained results revealed that the mortality rate was $90 \%$ and $60 \%$ in control groups and fish fed diet containing probiotics $\left(1 \times 10^{9} \mathrm{CFU} / \mathrm{g}\right.$ feed $)$ groups respectively and the relative percent of survival was $33.3 \%$ ( Table ,.8).

\section{Discussion}

In the current investigation, the probiotic Bacillus subtilis was isolated and characterized from digestive tract of apparently healthy Nile tilapia collected from production ponds of Central Laboratory of 
Aquaculture Research, Egypt. Bacillus subtilis, a saprophytic Grampositive, spore forming, rode shape bacteria, is not a animal or human pathogen, nor is it toxigenic like the other members of this genus (U.S. EPA, 1997). In addition, this species is known to be non- or low virulent and requires very high bacterial number for causing disease in human (Mathialagan Kavitha, et al., 2018 ). The isolated strain of Bacillus subtilis was gram positive, Catalase positive that showed the ability to ferment Esculin, glucose, dextrose, sucrose, glycerol, salicin and malonate. The present results have been found to be similar to the findings of earlier investigations (Rajashekhar, et al., 2017 and Lee, et al., 2017). As such, an extensive research on Bacillus was initiated only 15 years ago (Hong, et al., 2005; Mazza, 1994; Sanders et al., 2003) and consequently a number of Bacillus spp. were evaluated for their efficiency in various livestock production sectors like cattle, poultry, and fishery. The sequence of $16 \mathrm{~S}$ rRNA was frequently used for bacterial classification at species level ( Alam. et al ., 2011) The genes encoding DNA gyrase beta subunit (gyrB) and RNA polymerase beta subunit (rpoB) were previously used as phylogenetic markers in identification and delineation of the genus Bacillus (Guo, et al. 2012). Thus in this study, the bacteria isolated from Nile tilapia digestive tract was exactly confirmed as $B$. subtilis species by phenotypic characterization using API 20E and detection of Bacillus subtilis 16S rRNA._Safety evaluation of the selected candidate should be non-pathogenic to the host, which is an important precondition towards consideration of it as probiotic ( Verschuere et al., 2000). In the present study, biosafety experiment demonstrated that isolated strain of $B$. subtilis isolate was safe to Nile tilapia. ( Banerjee, et al., 2017) reported that the B. subtilis are safe to be as probiotics for aquaculture application. The bile salt tolerance is essential for bacterial colonization and metabolic activity in the small intestine during the host (Havenaar, et al., 1992). In the present study Bacillus subtilis isolate was able to survive in wide range of bile concentration of $2,5,5.0,7 \%$ and even higher up to $10 \%$, as reported earlier by ( Lee et al. 2017). Hemolytic activity is one of the pathogenic properties of bacteria, as it facilitates infection by microbial entry in to the small lesions in the mucous and skin ( Madigan et al., 1984). In the present study the isolated strain of Bacillus subtilis did not show any haemolytic activity on blood agar. Similarly, (Ramesh ,et al. 2015 ) have confirmed that Bacillus spp., have showed the non-haemolytic activity. (Mathialagan Kavitha, et al ., 2018 ) reported that Bacillus subtilis strains did not show any haemolytic activity against human blood in the blood agar medium. The required properties for a bacterium to be 
considered as a potential aquatic probiotic are that it must not only be safe for fish, but also do not harbor acquired and transferable antibiotic resistance (Vizoso Pinto, et al., 2006). In addition, antibiotic susceptibility assay showed that the isolate was sensitive to Norfloxacin, Levofloxacin, Streptomycin, Gentamycin, Trimethoprime /sulphamethoxazole, Amoxicillin and Ampicillin /sulbactam. Resistant to Cefuroxime and Flucloxacillin. Xia Guo et al 2016 ) founded that isolated stains of B.subtilis were sensitive to vancomycin, gentamicin, erythromycin, kanamycin, tetracycline, and chloramphenicol, but resistant to clindamycin and streptomycin . ( Mathialagan Kavitha, et al, 2018 ) found that $B$. subtilis found to be susceptible to the antibiotics Viz; kanamycin , ampicillin, erythromycin , amoxicillin, gentamycin , streptomycin, penicillin- G, chloramphenicol, , rifampicin and tetracycline. Antagonism between microorganisms is widespread in nature. Bacillus species was found to be effective to inhibit the growth of Pseudomonas fluorescens, Aspergillus niger, Saccharomyces sp, Fusarium moniliforme, Rhizoctonia sp. and Escherichia coli. (Xia Guo, et al., 2016) The inhibitory activities against some tested pathogens demonstrated that B. subtilis could produce antibacterial substances (such as bacteriocin, fengycin, bacilysin, surfactins, iturin, subtilin, and/or sublancin) as previous studies have shown (Ansari, et al., 2012) . The antimicrobial activities of $B$. subtilis might be due to its competition for nutrients with other bacteria (Moriarty, 1998). In the present study, antimicrobial activity of the isolated strain Bacillus subtilis against bacterial fish pathogen showed that the probiotic B. subtilis was efficient in inhibiting the growth of Aeromonas hydrophila and Pseudomonas aeruginosa. Probiotic bacteria have the ability to release chemical substances with bacteriostatic or bactericidal effect on pathogenic bacteria that are in host intestine, thus representing a barrier against the proliferation of opportunistic pathogens. In general, the antibacterial effect is due to one or more of the following factors: antibiotic production, bacteriocins, siderophores, enzymes (lysozymes, proteases) and/or hydrogen peroxide, as well as alteration of the intestinal $\mathrm{pH}$ due to the generation of organic acids (Verschuere, et al., 2000). The parallel use of biological products namely the probiotic is recently the goal of the disease biocontrol strategy in aquaculture as they modify the fish associated microbial community and improve the fish health (Gibson and Roberfroid, 1995 ). Probiotics have a beneficial effect on the digestive processes of aquatic animals because probiotic strains synthesize extracellular enzymes such as proteases, amylases, and lipases as well as provide growth factors such as vitamins, fatty acids, and 
aminoacids ( Balc'azar, et al 2006) . The hematological parameters are important assessments for fish nutrition and health. (Das, et al., 2013). In the present study, the isolated B. subtilis supplementation in Nile tilapia fed displayed an enhancement in hematological parameters at the end of feeding trials than those of the control. These results confirmed the safe harmless beneficial use of B. subtilis as probiotic on Nile tilapia diet. (Rasha, et al., 2018 ) found that all probiotic supplemented groups had higher hemoglobin content, platelet counts, MHC and MCHC compared with the control group. The results indicated a significant improvement of liver function tests which could be attributed to the immune- modulatory effect of $B$. subtilis on the liver cells which activate the anabolic capacity of the hepatocytes to produce blood proteins and this was also supported by the results of hepatic enzymes analysis which decreased in $O$. niloticus fed on probiotics in comparison to control group indicating a normal, positive and beneficial effect on maintenance of the integrity of hepatocytes . These results were supported by several authers ( Jessus , et al. 2002); (Nayak, et al. 2004) and ( Safinaz, 2006 ). In the present work, serum lysozyme activity, Nitroblue tetrazolium activity were enhanced in groups supplemented with isolated Bacillus subtilis after 7 weeks compare with Control groups as shown in Table (7). The serum lysozyme is used as an indicator of innate immune response in fish ( Tort, et al., 2003). The lysozyme is a fish defence element, which causes hydrolysis of the $\mathrm{N}-$ acetylmuramic acid and $\mathrm{N}$ acetylglucosamine which are constituent of the pepidoglycan layer of bacterial cell wall ( Ellis, 1999). In agreement with the present results, ( Addo, et al 2016) found that upon dietary supplementation of tilapia with strain NZ86 for 21 days, plasma lysozyme activity also was significantly greater. Plasma lysozyme content was also increased after 51 days of supplementation with both B. subtilis NZ86 and O14VRQ ( $<$ 0.05). The result from this time-period indicates the ability of both candidates for long-term effects in immunity, which is similar to the findings of Sun et al. after feeding grouper (Epinephelus coioides) with two different bacilli for 60 days ( Sun ,. et al 2010 ). The nitroblue tetrazolium (NBT) assay is mostly used to measure the oxidative radical production by leukocytes in the defence against pathogens (Cook, et al., 2003 and Sahoo,et al., 2005 ). The NBT reduction is a simple assay widely used to demonstrate the production of superoxide anion. The NBT accepts electrons from a variety of donor substances, such as superoxide, and thus is converted into a reduced form which precipitates as a blue-black insoluble material (formazan) on the cytoplasm of phagocytes. ( Sheng Zhoua, et al., 2019 ) found that dietary containing $B$. subtilis $7 \mathrm{k}$ administration at $10^{6}, 10^{8}$ 
and $10^{10} \mathrm{cfu}$ g- 1 for 8 weeks significantly increased the respiratory burst activity in Hulong grouper. The present study showed high mortality rate in A. hydrophila challenged Nile tilapia that were fed on basal diet (90\%) compared with that were supplemented with Bacillus subtilis $(60 \%)$.This evidence suggests that the increase of fish resistance to bacterial pathogens is related to the enhancement of antibacterial activity and immunity derived from the bacterial probiotics administered by the fish. Similar results were reported by (Saputra , et al., 2016 ) This may be due to the ability of Bacillus spore to resist gastrointestinal conditions, survive and transit cross gastrointestinal tract, germinate and vegetate with heterologous antigen expression before being excreted (Duc. et al., 2003 ).

Table (2) Biochemical characteristics of isolated bacillus subtilis using API 20E.

\begin{tabular}{|l|l|}
\hline REACTION & Bacillus subtilis \\
\hline Gram stain\& shape & + Rod \\
\hline Catalase & + \\
\hline O/F test & Oxidation \\
\hline$\beta$-galactosidase & - \\
\hline Arginine dihydrolase & - \\
\hline Lysine decarboxylase & - \\
\hline Ornithine decarboxylase & - \\
\hline Citrate utilisation & + \\
\hline H2S production & - \\
\hline Urea hydrolysis & - \\
\hline VP & + \\
\hline Tryptophan deamination & - \\
\hline Indole production & - \\
\hline Gelatin hydrolysis & + \\
\hline Glucose fermentation & + \\
\hline Mannitol & + \\
\hline Inositol & + \\
\hline Sorbitol & + \\
\hline Rhamnose & + \\
\hline Sucrose & + \\
\hline Melibiose & - \\
\hline Amygdalin & - \\
\hline Arabinose & - \\
\hline Nitrate reduction & + \\
\hline
\end{tabular}


Table (3) Bile tolerance test, showing that the B.subtilis isolate was able to survive at increasing concentration of bile.

\begin{tabular}{|l|l|l|l|}
\hline Antibiotic & Symbol & $\begin{array}{l}\text { Conc. } \\
(\mathbf{m c g})\end{array}$ & Reaction \\
\hline Levofloxacin & Lev & $\mathbf{5}$ & S \\
\hline Norfloxacin & Nor & $\mathbf{1 0}$ & S \\
\hline Trimethoprim/sulphamethazole & SXT & 25 & S \\
\hline Flucloxacillin & Cx & $\mathbf{5}$ & R \\
\hline Amoxicillin & AX & 25 & S \\
\hline Cefuroxime & Ctx & $\mathbf{3 0}$ & R \\
\hline Ampicillin/sulbactam & SAM & 20 & S \\
\hline Gentamycin & CN & $\mathbf{1 0}$ & S \\
\hline Streptomycin & S & 10 & S \\
\hline
\end{tabular}

Table (4) Antibiotic sensitivity of isolated Bacillus subtilis

\begin{tabular}{|c|c|c|}
\hline \multirow{2}{*}{ Bile concentration } & \multicolumn{2}{|c|}{ B. subtilis Survivability \% } \\
\cline { 2 - 3 } & $3 \mathrm{hr}$ & $\mathbf{6 ~ h r}$ \\
\hline $2.5 \%$ & $\mathbf{7 1}$ & $\mathbf{5 0}$ \\
\hline $5 \%$ & $\mathbf{6 8}$ & $\mathbf{4 7}$ \\
\hline $7.5 \%$ & $\mathbf{6 5}$ & $\mathbf{4 5}$ \\
\hline $10 \%$ & 55 & $\mathbf{4 0}$ \\
\hline
\end{tabular}

S:- Sensitive

R:-Resistant

Table (5) Effects of the experimental treatment on the hematological parameters of Nile tilapia after 7 weeks of feeding means + - SE.

\begin{tabular}{|l|l|l|}
\hline $\begin{array}{l}\text { Hematological } \\
\text { parameter }\end{array}$ & $\begin{array}{l}\text { Control } \\
\text { groups }\end{array}$ & $\begin{array}{l}\text { B. subtilis treatment } \\
\text { groups }\end{array}$ \\
\hline Hb\% & $\mathbf{1 0 . 4 6} \pm \mathbf{0 . 1 4}$ & $\mathbf{1 1 . 2 6} \pm \mathbf{0 . 1 7}$ \\
\hline RBCs 1X 10 $/ \mathbf{m m 3}$ & $1.6 \pm 0.014$ & $\mathbf{2 . 0} \pm \mathbf{0 . 0 5 3}$ \\
\hline HCT \% & $\mathbf{2 1 . 1} \pm \mathbf{0 . 1 2}$ & $\mathbf{2 2 . 3} \pm \mathbf{0 . 2 4}$ \\
\hline WBCs 1X 10 $/ \mathbf{m m 3}^{3}$ & $\mathbf{5 0 . 0} \pm \mathbf{0 . 1 0}$ & $\mathbf{5 7 . 2} \pm \mathbf{0 . 1 7}$ \\
\hline
\end{tabular}


Table (6) Effects of the experimental treatments on the biochemical parameters of Nile tilapia after 7 weeks of feeding

\begin{tabular}{|l|l|l|}
\hline $\begin{array}{l}\text { Biochemical } \\
\text { parameter }\end{array}$ & $\begin{array}{l}\text { Control } \\
\text { groups }\end{array}$ & $\begin{array}{l}\text { B. subtilis treatment } \\
\text { groups }\end{array}$ \\
\hline ALT IU/ml & $\mathbf{3 3} \pm \mathbf{2 . 0 8}$ & $\mathbf{2 5 . 0} \pm \mathbf{1 . 0}$ \\
\hline AST IU/ml & $\mathbf{5 9 . 3} \pm \mathbf{1 . 2 0}$ & $\mathbf{5 3 . 3} \pm \mathbf{1 . 4 5}$ \\
\hline $\begin{array}{l}\text { Total protein } \\
\text { gm/dl }\end{array}$ & $2.47 \pm \mathbf{0 . 0 2 1}$ & $\mathbf{2 . 8 6} \pm \mathbf{0 . 0 2 6}$ \\
\hline Albumin gm/dl & $1.37 \pm 0.011$ & $1.61 \pm \mathbf{0 . 0 0 0 8}$ \\
\hline
\end{tabular}

Table (7) Effects of the experimental treatment on the Immunological parameters of Nile tilapia after 7 weeks of feeding

\begin{tabular}{|l|l|l|}
\hline $\begin{array}{l}\text { Immunological } \\
\text { parameter }\end{array}$ & $\begin{array}{l}\text { Control } \\
\text { groups }\end{array}$ & $\begin{array}{l}\text { B. subtilis treatment } \\
\text { Groups }\end{array}$ \\
\hline Lysozyme $(\mu \mathrm{g} / \mathrm{mL})$ & $\mathbf{2 . 4 9} \pm \mathbf{0 . 0 6}$ & $\mathbf{3 . 2 0} \pm \mathbf{0 . 0 3 4}$ \\
\hline NBT $(\mathrm{mg} / \mathrm{ml})$ & $\mathbf{0 . 3 9 6} \pm \mathbf{0 . 0 6}$ & $\mathbf{0 . 6 4 4} \pm \mathbf{0 . 0 6}$ \\
\hline
\end{tabular}

Table ( 8 ) challenge test and RPS after 14 days post-infection of $A$. hydrophila.

\begin{tabular}{|c|c|c|c|c|}
\hline \multirow{2}{*}{ A.hydrophila } & \multirow{2}{*}{$\begin{array}{c}\text { Rout } \\
\text { Of } \\
\text { injection }\end{array}$} & \multicolumn{2}{|c|}{$\%$ of mortality } & \multirow{2}{*}{$\begin{array}{c}\text { RPS } \\
\%\end{array}$} \\
\hline & & Control & Treatment & \\
\hline $\begin{array}{c}0.1 \mathrm{ml} / \text { fish } \\
\left(1.5 \times 10^{8}\right. \\
\text { cells } / \mathrm{ml})\end{array}$ & $\mathbf{I} / \mathbf{P}$ & $90 \%$ & $60 \%$ & 33.3 \\
\hline
\end{tabular}

RPS $=$ Relative percent of survival 


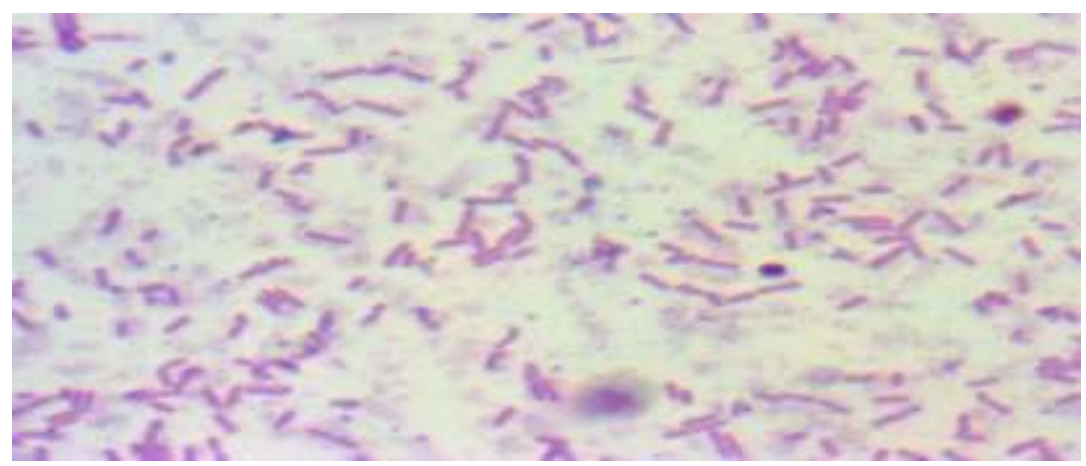

Fig ( 1 ) Gram positive rods of Bacillus subtilis, under light microscope (X 1000).

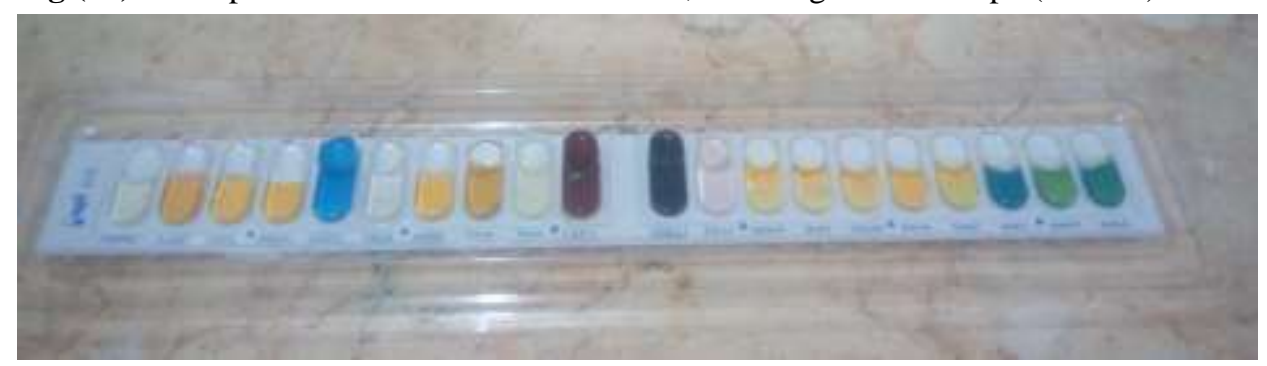

Fig (2) Phenotypic characterization of the isolated strain Bacillus subtilis using API20E

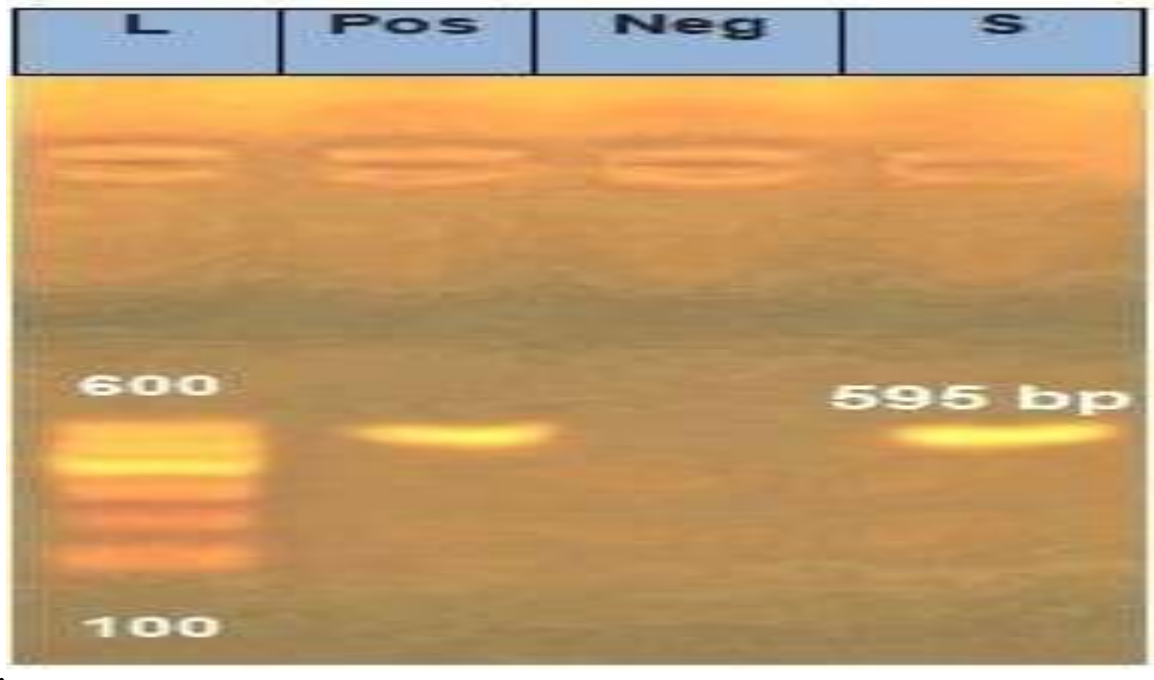

$\mathrm{S}=$ Sample, Neg = control negative, Pos $=$ Control positive, L:- = Lan marker

Fig (3) The PCR result showing that the primer used successfully detected the $16 \mathrm{~s}$ rRNA for isolated strain of Bacillus subtilis .The size of amplicon for the gene of interest was $595 \mathrm{bp}$. 


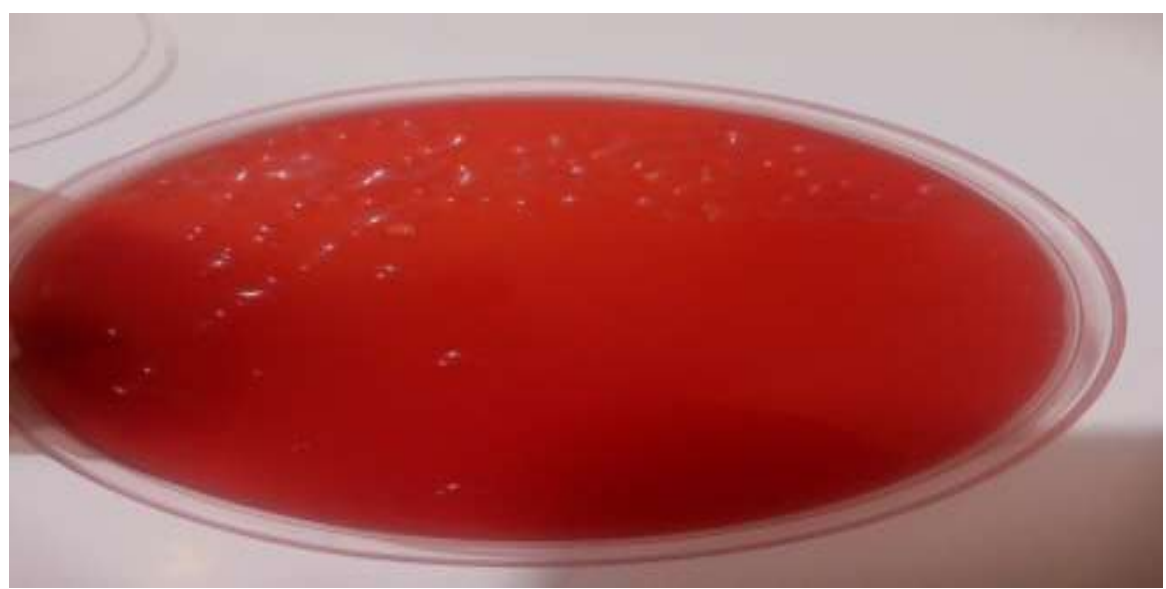

Fig (4) The haemolytic activity of the isolated Bacillus subtilis strain did not show any haemolytic activity against human blood in the blood agar medium.

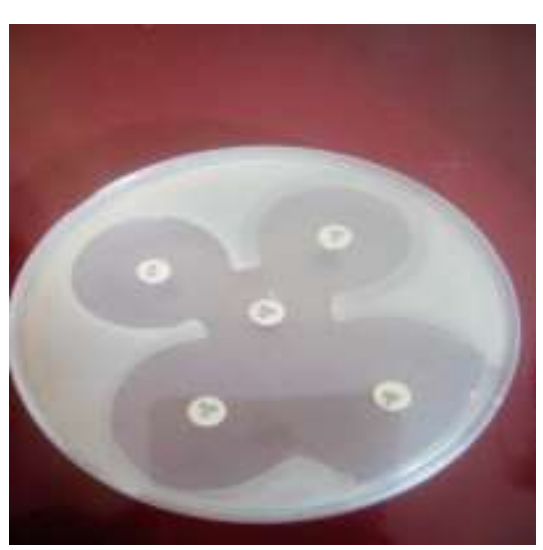

Fig (5) Antibiotic sensitivity test Norfloxacin, Levofloxacin, /sulphamethoxazole, Amoxicillin Cefuroxime and Flucloxacillin.

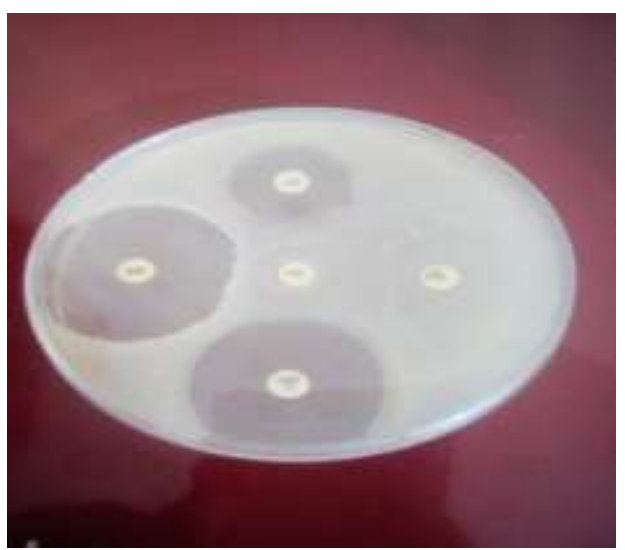

for the isolated Bacillus subtilis was sensitive to Streptomycin, Gentamycin, Trimethoprime and Ampicillin /sulbactam and resistant to 
Fig (6) T he antimicrobial activity of the probiotic B. subtilis against Aeromonas hydrophila..

Fig (7) The antimicrobial activity of the probiotic B. subtilis against Pseudomonas aeruginosa..

\section{Acknowledgment}

I would like to thank, Dr. Ahmed Erfan, Head of Biotechnology Unit, Reference Lab for Veterinary Quality control, Animal Heath Research Institute, Dokki, Giza, Egypt . For his help in molecular detection of Bacillus subtilis 16s rRNA . 


\section{References}

Addo, S., Carrias, A.A. , Williams, M.A., Liles, M.R., Terhune, J.S., and Davis, D.A. ( 2017) : Effects of Bacillus subtilis strains on growth, immune parameters, and Streptococcus iniae susceptibility in Nile tilapia, Oreochromis niloticus, J. World Aquacult. Soc. 48 ,(2), 257-267.

Ahire, J.J., Patil, K.P., Chaudhari, B.L., and Chincholkar, S.B., (2011): A potential probiotic culture ST2 produces siderophore 2,3dihydroxybenzoylserine under intestinal conditions. Food Chemistry volume 127, (2 ),387 - 393.

Alam, S.I., Bansod, S., Goel, A.K., and Singh, L. (2011) : Characterization of an Environmental Strain of Bacillus thuringiensis from a Hot Spring in Western Himalayas.Current Microbiology 62, (2), 547- 556.

Amend, D.F. (1981) : Potency testing of fish vaccines, Dev. Biol. Stand. 49, 447-454.

Ansari, A., Aman, A., Siddiqui, N.N., Iqbal, S., and ul Qader, S.A. (2012) : Screening, isolation and production from Bacillus subtilis KIBGE IB-17,Pak. J. Pharm. Sci. 25, 195e201.

Argyri, A.A., Zoumpopoulou, G., Kimon, A.G., Karatzas, K.A., Tsakalidou, E., Nychas,G.J., Panagou, E., and Tassou, C., (2013) : Selection of potential probiotic lactic acid bacteria from fermented olives by in vitro tests. Food Microbiology , 33 (2) 282 -291.

Austin, B., Stuckey, L., Robertson, P., Effendi, I., and Griffith, D., (1995) : A probiotic strain of Vibrio alginolyticus effective in reducing diseases caused by Aeromonas salmonicida,Vibrio anguillarum and Vibrio ordalii. Journal of Fish Diseases ,18 (1) 93 - 96.

Balcázar, J.L., De Blas, I., Ruiz-Zarzuela, I., Cunningham, D., Vendrell, D., and Muzquiz, J.L., (2006): The role of probiotics in aquaculture. Veterinary Microbiology , 114 (3-4) 173 - 186.

Banerjee, G., Nandi, A., and Ray, A.K., (2017) : Assessment of hemolytic activity, enzyme production and bacteriocin characterization of Bacillus subtilis LR1 isolated from the gastrointestinal tract of fish. Archives of Microbiology ,199 (1) 115 - 124.

Bauer AW, Kirby WM, Sherris JC, and Turck M. (1966):Antibiotic susceptibility testing by a standardized single disk method. American Journal of Clinical Pathology, 45issue 4_ts $493-496$. 
Boone, R .B., BurnSilver, S.B, Thornton, PK, Worden, J.S, and Galvin, K. A.. (2005): Quantifying Declines in Livestock Due to Land Subdivision. Rangeland Ecology\&Management, 58,523 - 532.

Chi, C., Jiang, B.. Yu, X.-B, Liu, T.-Q Xia L, and Wang, G.-X. (2014) : Effects of three strains of intestinal autochthonous bacteria and their extracellular products on the immune response and disease resistance of common carp, Cyprinus carpio. Fish \& Shellfish Immunology , 36,(1s) 9 - 18.

Cook, MT., Hayball, PJ., Hutchinson, W., Nowak, BF. and Hayball, JD., (2003) : Administration of a commercial immunostimulant preparation, Eco Ativa ${ }^{\mathrm{TM}}$ as a feed supplement enhances macrophage respiratory burst and the growth rate of snapper (Pagrus auratus, Sparidae (Bloch and Schneider)) in winter. Fish and Shellfish Immunology,. 14,. (4), p. 333-345.

Das, A., Nakhro, K., Chowdhury, S., and Kamilya, D. (2013):Effects of potential probiotic Bacillus amyloliquifaciens FPTB16 on systemic and cutaneous mucosal immune responses and disease resistance of catla (Catla catla), Fish \& Shellfish Immunology, 35, (5) 1547 1553.

Decie, S. and Lewis, S. (1991): Practical haematology 7th ed., Churchill Livingstone, London.diseases in fish. Appl Environ Microbiol;67:2430e5.

Duc, L.H., Hong, H.A., Barbosa, T.M., Henriques, A.O. and Cutting, S.M.( 2004) : Characterisation of Bacillus probiotics available for human use.Applied and EnvironmentalMicrobiology ,70, (4 ) 2161 2171 ,

Ellis, E. (1999): Immunity to bacteria in fish. Fish \& Shellfish Immunology ,9 (4) , 291 - 308, https://doi.org/10.1006/fsim.1998.0192

Gatesoupe, F., (1999) : The use of probiotics in aquaculture. Aquaculture, 180 ( 1-2 ) $147-165$.

Gibson, G. R. and Roberfroid, M. B., (1995) : Dietary modulation of the human colonic microbiota introducing the concept of prebiotics. The Journal of Nutrition ,125 (6)1401 - 1412.

Gomez, G.D. \& Shen, M.A. (2008) : Influence of probiotics on the growth and digestive enzyme activity of whitePacific shrimp (Litopenaeus vannamei). Journal of Ocean University of China , 7 (2) $215-218$. 
Gomez-Gil B, Roque A, Turnbull JF (2000) : The use and selection of probiotic bacteria for use in the culture of larval aquatic organisms. Aquaculture, 191 (1-3) 259 - 270.

Guo, Q.G., Li, S.Z., Lu, X.Y., Li, B.Q. , Stummer, B., and Dong, W.X. et al., (2012) : phoR sequencesas a phylogenetic marker to differentiate the species in the Bacillus subtilisgroup,. Canadian Journal of Microbiology , 58 , (11) 1295 - 1305, Han, Y., E. Liu, L. Liu, B. Zhang, Y. Wang, M. Gui, R. Wu and P. Li. (2015) : Rheological, emulsifying and thermostability properties of two exopolysaccharides produced by Bacillus amyloliquefaciens LPL061. Carbohydrate Polymers , 115, 230 -237.

Havenaar, R., Brink, B.T., Huis isn't Veld, H.J.H., (1992) : Selection of strains for probioticuse. In: Fuller, R. (Ed.), In Probiotics. Chapman \& Hall, London, pp. 209-224.

Hong, H.A., Duc, L.H., \& Cutting, S.M., (2005) : The use of bacterial spore formers as probiotics. FEMS Microbiology Reviews ,29, (4) $813-835$.

Kuan-Fu Liu , Chiu-Hsia Chiu, Ya-Li Shiu, Winton Cheng and, Chun-Hung Liu (2010): Effects of the probiotic, Bacillus subtilis E20, on the survival, development, stress tolerance, and immune status of white shrimp,Litopenaeus vannamei larvaeFish \& Shellfish Immunology, 28, 837e844.

Jessus ortuno, Alberto cuesta, Alejandro Rodriguez, M.Angeles Eesteban and Jose Meseguer. (2002): Oral administration of yeas, Saccharomyces cerevisiae, enhances the celluler innate immune response of gillhead seabream,Sparus aurata L. Veterinary Immunology and Immunopathology, 85 , (1-2 ) 41 - 50.

Lee, A., Cheng, K.C., \& Liu, J.R., (2017) : Isolation and characterization of a Bacillus amyloliquefaciens strain with zearalenone removal ability and its probiotic potential. PLoS One 12 (8).

Lee, N. K., Kim, S. Y., Choi, S. Y., \& Paik, H. D. ( 2013) : Probiotic Bacillus subtilis KU201 having antifungal and antimicrobial properties isolated from kimchi. Food Science and Biotechnology , 22 , (5), on 1 5.

Lied, E., , Gezerde, Z. \& Braskhan D.R., (1975) : Simple and rapid technique for repeated blood sampling in Rainbow trout. Journal of the Fisheries Research Board of Canada , 32 , (5) , 699 - 701. 
Madigan, M., Martinko, J., and Parker, J., (1984): Brock Biology of Microorganisms, 9th ed. Prentice Hall, Englewood Cliffs, NJ: USA.

Mathialagan Kavitha, Manickam Raja, \& Pachiappan Perumal (2018): Evaluation of probiotic potential of Bacillus spp. isolated from the digestive tract of freshwater fish Labeo calbasu (Hamilton, 1822) Aquaculture Reports 11 (2018) 59-69.

Mazza, P. ( 1994) : Helvetica Chimica Acta , 77 (1), 1- 18.

Mohapatra, S., Chakraborty, T., Kumar, V., Deboeck, G., and Mohanta, K., (2013) : Aquaculture and stress management: a review of probiotic intervention. Journal of Animal Physiology and Animal Nutrition, 97 (3), 405 - 430.

Moriarty, D.J.W., (1998.) : Control of luminous Vibrio species in penaeid aquaculture ponds. Aquaculture, 164 (1-4), 351 - 358.

Mukherjee, A., and Ghosh, K., (2016) : Antagonism against fish pathogens by cellular components and verification of probiotic properties in autochthonous bacteria isolated from the gut of an Indian major carp, Catla Catla (Hamilton). Aquaculture Research , 47 , (7 ), 2243- 2255.

Nayak, A.K., Das, B.K., Kohli, M.P.S., and Mukherjee, S.C. (2004) :The immunosuppresive effect of $\alpha$-permethrin on Indian major carp, rohu, Labeo rohita. Fish \&Shellfish Immunology , 16, (1), 41 - 50.

Nayak, S.K., (2010) : Probiotics and immunity: a fish perspective. Fish Shellfish Immunol.29 (1), 2-14.

Nayak, S.K., Swain, P., and Mukherjee, S.C., (2007): Effect of dietary supplementation of probiotic and vitamin $\mathrm{C}$ on the immune response of Indian major carp, Labeo rohita. Fish \& Shellfish Immunology , 23 , (4), 892 - 896.

Newaj-Fyzul, A., Adesiyun, A.A., Mutani, A. , Ramsubhag, A. , Brunt, J., and Austin, B. (2007) : Bacillus subtilis AB1 controls Aeromonas infection in rainbow trout (Oncorhynchus mykiss, Walbaum), Journal of Applied Microbiology , 103 , (5) , 1699 - 1706.

Nikoskelainen, S., Salminen ,S., Bylund, G., \& Ouwehand AC. (2001) : Characterization of the properties of human- and dairy-derived probiotics for prevention of infectious diseases in fish. Applied and Environmental Microbiology , 67, (6), 2430 - 2435.

Priest, F., M. Goodfellow, Shute., L. and Berkeley., R. (1987) : Bacillus amyloliquefaciens sp. nov., nom rev. International Journal of Systematic Bacteriology , 37, (1), 69 - 71. 
Rajashekhar, M., Shahanaz, E., Vinay, K., (2017) : Biochemical and molecular characterization of Bacillus spp. isolated from insects. J. Entomol. Zool. Stud. 5 (5), 581-588.

Ramesh, D., Vinothkanna, A., Rai, A.K., and Venkada Subramanian, V.( 2015) : Isolation of potential probiotic Bacillus spp. and assessment of their subcellular components to induce immune responses in Labeorohita against Aeromonas hydrophila. Fish Shellfish Immunol. 45, 268-276.

Rasha, M.R., El-Hadya, M.A., Khaled, M. S., and Hassanin M.El. (2018) : Comparative study of three predominant gut Bacillus strains and a commercial B. amyloliquefaciens as probiotics on the performance of Clarias gariepinus. Fish and Shellfish Immunology 80 (2018) 416-425.

Reitman, S. and Frankel, S. (1957) : A colorimetric method for the determination of serum glutamic oxaloacitic and glutamic pyruvic transaminases. American Journal of Clinical Pathology , 28, (1), 56 63.

Safinaz, R.A.A. (2006) : Clinicopathological studies on the effect of growth promoters in Nile tilapia. M.V.Sc., Thesis, Faculty of Veterinary Medicine, Cairo University.

Sahoo, PK., Kumari, J. and Mishra, BK. ( 2005) : Non- specific immune responses in juveniles of Indian major carps. Journal of Applied Ichthyology, 21, (2) 151 - 155.

Sanders, M.E., Morelli, L., and Tompkins, T.A., ( 2003) : Sporeformers as Human Probiotics: Bacillus, Sporolactobacillus, and Brevibacillus. Comprehensive Reviews in Food Science and Food Safety, 2, (3), $101-110$.

Saputra, F., Shiu, Y.L, Chen, Y.C., Puspitasari, A.W., Danata, R.H., and Liu, C.H. et al. (2016) : Dietary supplementation with xylanase-expressing B. amyloliquefaciens R8 improves growth performance and enhances immunity against Aeromonas hydrophila in Nile tilapia (Oreochromis niloticus). Fish \& Shellfish Immunology , 58, 397-405.

Schäperclaus, W., Kulow, H., \& Schreckenbach, K. (1992) : Fish Disease. A.A. Balkema, Rotterdam, the Netherlands.

Sharifuzzaman, S.M., \& and Austin, B., (2009) : Influence of probiotic feeding duration on disease resistance and immune parameters in rainbow trout. Fish \& Shellfish Immunology, $27,(3), 440-445$. 
Sheng Zhoua,1, Deli Songb,c,1, Xiaofeng Zhoub, Xinliang Maob, Xuefeng Zhoud, Sunli Wanga,Jingguang Weia, Youhua Huanga, Wenxiong Wange, Su-Mei Xiaob, and Qiwei Qin (2019) : Characterization of Bacillus subtilis from gastrointestinal tract of hybrid Hulong grouper (Epinephelus fuscoguttatus $\times$ E. lanceolatus) and its effects as probiotic additives. Fish and Shellfish Immunology 84 (2019) 1115-1124.

Siwicki, AK. (1989) : Immunostimulating influence of levamisole on nonspecific immunity in carp $(C$. carpio). Developmental \& Comparative Immunology volume13 issue 1 on pages 87 to 91 .

Stoskopf, M. K. 1993. Fish medicine Ed., W.B. Sainders Company, London.

Sun, Y.Z. , Yang, H.L. , Ma, R.L., and Lin, W.Y. (2010) : Probiotic applications of two dominant gut Bacillus strains with antagonistic activity improved the growth performance and immune responses of grouper Epinephelus coioides, Fish \& Shellfish Immunology , 29, (5) 803 - 809.

Thrall, M.A. (2004) : Veterinary Hematology and Clinical Chemistry ED., Lippincott Williams and Wilkins, Maryland, USA..

Tort, L., Balasch, J. C. and Mackenzle, S., (2003) : Fish immune system. A crossroads between innate and adaptive responses. Imunología, vol. 22, no. 3, p. 277-286.

U.S. Environmental Protection Agency.(1997) : Bacillus subtilis Final risk assessment. http://www.epa.gov/ biotech_rule/pubsfra/fra009.htm, accessed May 11,2009.

Uma A, Abraham, TJ., and Sundararaj, V. (1999) : Effect of a probiotic bacterium, Lactobacillus plantarum on disease resistance of Penaeus indicus larvae. Indian J. Fish. 46(4): 367-373

Verschuere, L., Rombaut, G., Sorgeloos, P., and Verstraete, W., (2000): Probiotic bacteria as biological control agents in aquaculture. Microbiol. Mol. Biol. Rev. 64, 655-671.

Vizoso Pinto, M.G., Franz, C.M., Schillinger, U., and Holzapfel, W.H. (2006) : Lactobacillus spp.with in vitro probiotic properties from human faeces and traditional fermented products, Int. International Journal of Food Microbiology ,109 , (3 ), 205 - 214.

Wattiau, P.; Renard, M.-E. Ledent, P.; Debois, V.; Blackman, G. and Agathos, S.N. (2001) : A PCR test to identify Bacillus subtilis and closely related species and its application to the monitoring of 
wastewater biotreatment. Applied Microbiology and Biotechnology , 56, (5-6 ) 816 - 819.

Weichsebum, T.E., (1946) : An Accurate and Rapid Method for the Determination of Proteins in Small Amounts of Blood Serum and Plasma. American Journal of Clinical Pathology , 16 (3_ts) , 40 - 49 .

Wu, H-J., Sun, L-B., Li, C-B. , Li, Z-Z., Zhang, Z.,. Wen, X-B, Hu, Z., Zhang Y-L., and Li, S-K. (2014) : Enhancement of the immune response and protection against Vibrio parahaemolyticus by indigenous probiotic Bacillus strains in mud crab (Scylla paramamosain). Fish Shellfish Immunol., 41: 156-162.

Xia Guo, Dan-Dan Chen, Kai-Song Peng, Zheng-Wei Cui Xu-Jie Zhang Shun Li Yong-An Zhang. (2016) : Identification and characterization of Bacillus subtilis from grass carp (Ctenopharynodon idellus) for use as probiotic additives in aquatic feed. Fish \& Shellfish Immunology , 52, 74 -84.

Ziaei-Nejad, S., Rezaei, M.H., Takami, G.A., Lovett, D.L., Mirvaghefi, A.-R., and Shakouri, M., (2006) : The effect of Bacillus spp. bacteria used as probiotics on digestive enzyme activity, survival and growth in the Indian white shrimp Fenneropenaeus indicus. Aquaculture, $252,(2-4), 516-524$. 
خصائص البروبيوتك بسلس ستلس المعزولة من القتاة الهضمية لأسمالك البلطي

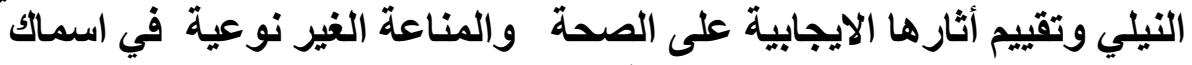
البلطي التيلي

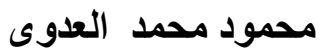

قسم بحوث صحة الأسماك ورعايتها ـ المعمل المركزي لبحوث الثروث الثرة السمكية ـ العباسةـ أبو

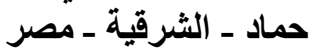

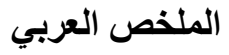

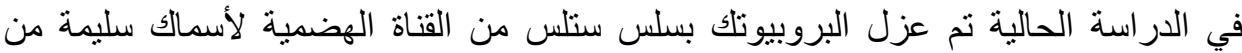

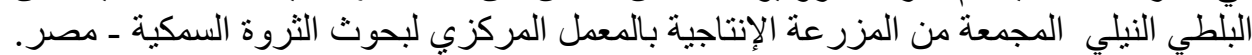

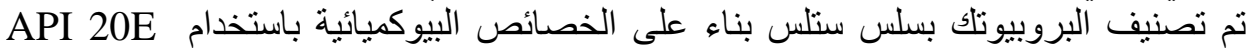

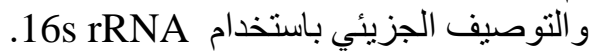

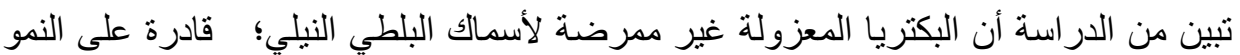

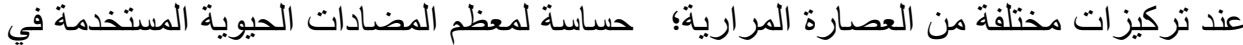

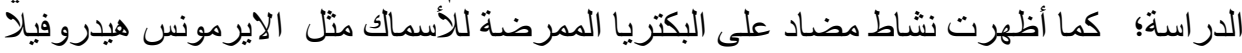

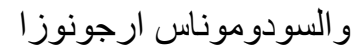

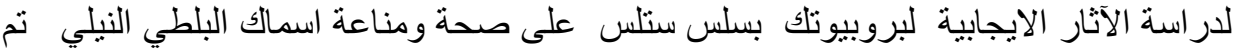

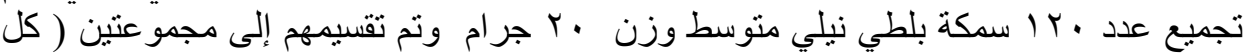

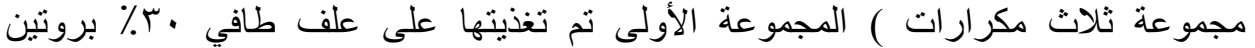

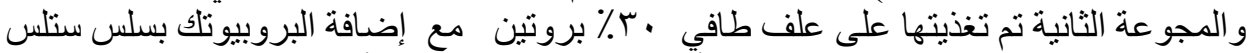

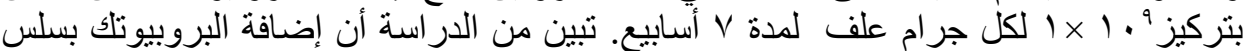

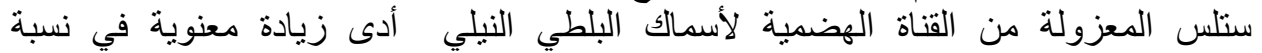

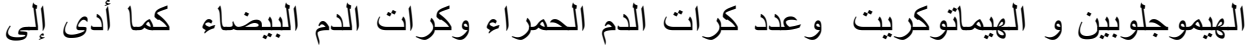

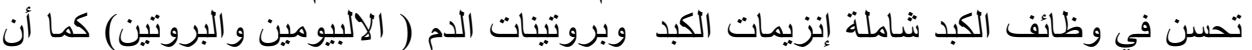

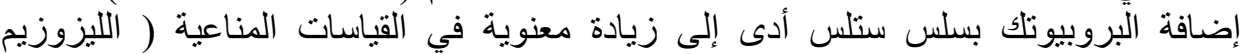

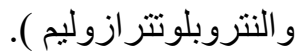

تم إجر اء العدوى الصناعية في نهاية التجربة بميكروب التبروب الايروموناسى هيدروفيلا وكانت نسبة

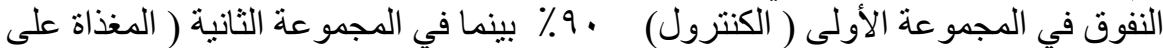

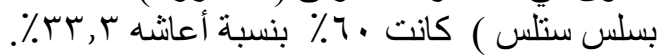

